\title{
Methane emission from Matsuo rice paddy field in light of different fertilizers, costs, profit and carbon credit
}

\author{
${ }^{1}$ Gergő Kun- ${ }^{1}$ Adrián Nagy- ${ }^{2}$ Shunsuke, Hanazawa- ${ }^{2}$ Maasa, Takahashi-2'Kazuyuki, Inubushi \\ ${ }^{1}$ University of Debrecen Faculty of Economics and Business Administration, Debrecen \\ ${ }^{2}$ Chiba University Graduate School of Horticulture, \\ Bioresource Science, Chiba, Japan \\ kun.gergo@econ.unideb.hu
}

\begin{abstract}
SUMMARY
Nowadays global warming is a major issue to our environment. This issue is generated by the modern human activities like industry and intensive agriculture. This research is about methane emission from rice paddy fields. The aim of the study is to lower the methane emission from the field with the help of using different type of fertilizers, whilst we keep in focus the efficient economic operation. The main experimental field is Matsuo paddy field, (Matsuo town, Sanbu city, Chiba prefecture) which is analyzed by the Chiba University's soil science laboratory, they provided the data for this study. During the study three type of fertilizer was analyzed which are all organic and the control was a regular chemical fertilizer. For all fertilizers the cost and income of the production were calculated and the profit was weighted with the methane emission what a specific fertilizer produced during the cultivation. In the future if the organic fertilizers are in focus than it is necessary to find a new material what can be competitive with the chemical fertilizers in focus of GHG emission or find an alternative way of the usage of methane in biogas production.
\end{abstract}

Keywords: Matsuo rice, methane emission, cost profit analysis, carbon credit

\section{ÖSSZEFOGLALÁS}

Napjainkban környezetünk egyik legnagyobb problémája a globális felmelegedés. A probléma fö forrása pedig leginkább a modern emberi tevékenység, mint például az ipar és az intenzív földmüvelés. A kutatásunk fö témája a rizsföldekröl felszabaduló metánkibocsátás elemzése. Célja a földekröl származó metán-emisszió csökkentése különbözö típusú trágyák felhasználásával, közben természetesen figyelembe véve a gazdaságos termelés szempontjait is. A fö kísérleti terület Japánban a Chiba prefektúrában lévö Matsuo város mellett elterülö rizsföld volt. A vizsgálatot a Chiba Egyetem Talajtani Tanszéke végezte, innen származnak a tanulmány alapadatai. A kisérlet során háromféle különbözö összetételü, természetes eredetü trágyatípust elemeztünk, a kontroll pedig általános összetételü mütrágya volt. Az összes trágyára vonatkozóan ki lett kalkulálva a költség, a jövedelem és a haszon. A számítások során a profitot súlyoztuk a metánkibocsátás értékével az egyes trágyatípusokra vonatkozóan, amely alapján értékelni lehet a metánkibocsátáson alapuló hatékonyságot. Ha természetes eredetü trágyák lesznek a termelés középpontjában, akkor a jövőben szükséges lesz egy olyan új anyagot találni, amely versenyképes lehet a mütrágyákkal az üvegházhatású gázok kibocsátásának tekintetében. Végsö esetben alternatív megoldást kell keresni a termelödö metán hasznositására, annak a biogáz-termelésbe történö becsatornázására.

Kulcsszavak: Matsuo rizs, metánkibocsátás, költség-haszon elemzés, carbon credit

\section{INTRODUCTION}

The $21^{\text {st }}$ century`s most important issue is the global warming. This issue is generated by the modern human activities like industry and intensive agriculture. The world's population continues to grow and, over the next 40 years, agricultural production will have to increase by some $60 \%$. Higher food, feed and fiber demand will place an increasing pressure on land and water resources, whose availability and productivity in agriculture may themselves be under threat from climate change (Popp et al. 2013). The beginning of this progress was at the $18^{\text {th }}$ century when the industrial revolution started in Great Britain and then in Europe and in some parts of North America. From this time the size of the industry is just increased all around the world and nowadays this is the biggest greenhouse gas emissive. Although Industry is responsible for most of the $\mathrm{CO}_{2}$ emission there are other significant greenhouse gases. The three most important greenhouse gases are carbondioxide $\left(\mathrm{CO}_{2}\right)$, methane $\left(\mathrm{CH}_{4}\right)$ and nitrous oxide $\left(\mathrm{N}_{2} \mathrm{O}\right)$. These are Long-lived greenhouse gases (LLGHGs),
$\mathrm{CO}_{2}$, methane $\left(\mathrm{CH}_{4}\right)$ and nitrous oxide $\left(\mathrm{N}_{2} \mathrm{O}\right)$, are chemically stable and persist in the atmosphere over time scales of a decade to centuries or longer (IPCC 2007). Total annual anthropogenic greenhouse gas (GHG) emissions (gigatonne of $\mathrm{CO}_{2}$-equivalent per year, $\mathrm{Gt} \mathrm{CO}_{2}$-eq/yr), in 2010 by gases: $\mathrm{CO}_{2}$ from fossil fuel combustion and industrial processes $32 \mathrm{Gt}(65 \%)$; $\mathrm{CO}_{2}$ from Forestry and Other Land Use (FOLU) 5.5 Gt (11\%); methane $\left(\mathrm{CH}_{4}\right) 8 \mathrm{Gt}(16 \%)$; nitrous oxide $\left(\mathrm{N}_{2} \mathrm{O}\right) 3 \mathrm{Gt}(6,2 \%)$; fluorinated gases covered under the Kyoto Protocol (F-gases) $1 \mathrm{Gt}(2 \%)$. Uncertainty about the global emissions of $\mathrm{CH}_{4}, \mathrm{~N}_{2} \mathrm{O}$ and the F-gases has been estimated at $20 \%, 60 \%$ and $20 \%$, respectively. 2010 was the most recent year for which emission statistics on all gases as well as assessments of uncertainties were essentially complete at the time. (IPCC 2014) Methane emission is contributing $16 \%$ towards global warming but the biggest emissive is not the industry for this GHG. Agricultural crop and animal production systems are the most important sources and sinks for atmospheric methane $\left(\mathrm{CH}_{4}\right)$. The major $\mathrm{CH}_{4}$ sources from this sector are ruminant animals, flooded rice fields, animal waste and 
biomass burning (Mosier et al. 1998). Climate change, like other environmental problems, involves an externality: the emission of greenhouse gases damages others at no cost to the agent responsible for the emissions (Stern 2006).

This research is about methane emission in rice paddy fields in case of using different type of fertilizers. Soils and their managements have important potentials to affect the production and consumption of these greenhouse gases (Hadi et al. 2010). In this study the main purpose is to know the actual cost of fertilizers at the fields. Form and amount of nitrogen fertilizer applied are other options for mitigating $\mathrm{CH}_{4}$ emission from rice paddy fields (Minami 1995). Currently, an area of approximately 154 million ha worldwide is dedicated to rice cultivation (FAO 2016). For the research this study will analyze the crop management at the Matsuo paddy rice field. There was used different type of fertilizers the amount of yield will be different and the methane emission will be different as well. If this information is known there will be different options how to manage the fields. There will be options how to be green and how to manage the land with less methane emission and more yields while trying to reduce the cost of it. Reducing the methane emission from rice paddy fields is a good thing for the environment but maybe it has some costs which make it difficult to use these methods in real economic environment. These issues can be the high price of special bacterial material fertilizer or the lower amount of yield from the fields. This study is looking for the answer of what crop management would be ideal for the farmer and to the environment as well.

\section{MATERIAL AND METHODS}

In this study the main question is how much does it cost to manage the field, in that case the focus will be the cost of fertilizers. The main experimental field is Matsuo paddy field, (Matsuo town, Sanbu city, Chiba prefecture) which is analyzed by the Chiba University's soil science laboratory. The size of the field is 1 tanbu which means $991736 \mathrm{~m}^{2}$ which is equal to almost 0,1 hectare. The field is divided into three equal parts. At each part one treatment is set up, all of them are organic fertilizer except the control one. The usage of organic type fertilizer is an important fact because it helps to keep the soil's natural properties and allow it to be a sustainable resource. The treatments contains one control field which is treated by regular chemical fertilizer. The chemical fertilizer's N:P:K ratio is the following, $\mathrm{N}: \mathrm{P}: \mathrm{K}=14: 16: 14$ (40 kg/10 are only when rice planting). The field is also treated with pesticide for this purpose "kusabue" was used whose main component is Cumyluron and Pentoxazon. The second treatment is urea $(3.1 \mathrm{~kg} /$ 10 are) plus rice straw ( $500 \mathrm{~kg} / 10$ are), that means only organic materials were used at the progress of cultivation. Straw is an agricultural by-product, the dry stalks of cereal plants. The rice straw is harvested the year before the usage from the same paddy field and it was cut into $2-3 \mathrm{~cm}$ size pieces. The urea is used in that case to adjust the $\mathrm{CN}$ ratio about 30 . The price of the rice straw can be variant from almost free to $25 \mathrm{JPY}$ per $\mathrm{kg}$ if it is used for bioethanol producing. But the price cannot be free because if it is from personal sources used for personal utilization it is always have some costs. The available amount of byproducts is greatly influenced by the capacity of the harvesting machines, the capacity needs of other tasks done at the time of the harvest and the intensity of the production (Bai et al. 2015). So in that case the price of the rice straw for using as fertilizer is 2 JPY per $\mathrm{kg}$ which makes it a very cheap one. The third treatment is urea $(3.1 \mathrm{~kg} / 10$ are $)$ plus rice straw (500 kg/10 are) plus bacterial material A (20 kg/10 are). Bacterial material A contains zeolite (microporous, including $\mathrm{SiO}_{2}, \mathrm{Al}_{2} \mathrm{O}_{3}, \mathrm{CaO}, \mathrm{MgO}, \mathrm{Na}_{2} \mathrm{O}, \mathrm{K}_{2} \mathrm{O}$ and some minerals) and spores of Bacillus subtilis and Clostridium acetobutylicum (Hanazawa et al. 2013). Bacterial material A is reported that it advanced rice straw decomposition on rice growing. Bacterial material $\mathrm{A}$ is a solution how to suppress the methane emission from the rice paddy fields. The zeolite with the two microbes is good way to decompose rice straw and fresh organic matter.

There is another microbial material solution which one is examined in a previous study but in this research the Matsuo field was not applied with this. This is a commercial microbial material solution (MMS) produced by EM Laboratory Co Ltd. (Shizouka, Japan) was used for bokashi preparation. According to the product information, the solution contains various microbes as mainly lactic acid bacteria and yeasts, of which population where 106-107 and 103 numbers $\mathrm{mL}^{-1}$, respectively (Kato et al. 2008). This will be called as bacterial material $\mathrm{C}$ hereinafter. The big difference between the two types is in the price. While bacterial material A costs $2700 \mathrm{JPY}$ per are bacterial material C costs 432.25 JPY per are which is a significant difference. Chemical fertilizer's ratio is the following, $\mathrm{N}: \mathrm{P}: \mathrm{K}=14: 16: 14$ (40 kg/10 are). This is only used while rice planting. The price of the chemical fertilizer is $3444 \mathrm{JPY}$ per $20 \mathrm{~kg}$, for $10 \mathrm{a} 40 \mathrm{~kg}$ have to be used so in Matsuo paddy rice field case this is $6832 \mathrm{JPY}$ per 1 tanbu. The concentrations of $\mathrm{CO}_{2}, \mathrm{~N}_{2} \mathrm{O}$, and $\mathrm{CH}_{4}$ were measured using gas chromatographs (GC-14B, Shimadzu, Japan) equipped with a thermal conductivity detector, electron capture detector and flame ionization detector, respectively. In this case of study will focus just on the methane emission and the cost of the fertilizers. If all these data are known it is possible to start the economic analysis of the rice paddy field. In this case the purpose of the study is to get information about three important questions. How to get more yields? What type of fertilizer has to be used for? How is it possible to earn the most yields with the less methane emission? To get these answers this study will calculate several economic rates. It is important to create a sustainable agriculture system. The nature and the importance of environmental issues-driven, holistic finds have approached to agriculture. The environmental, social and economic interests have to be weight with the same standards to consider. Sustainable agriculture is built on existing natural resources in the built environment.

\section{ECONOMIC CALCULATIONS}

To calculate the income we need to process simple economic calculations $\mathrm{I}=\mathrm{P}^{*} \mathrm{Q}$ income $=$ price* quantity 
The total yield is now known to get the income a very simple multiplication with price and quantity. The price of the rice is $200 \mathrm{JPY}$ per $\mathrm{kg}$ so it has to be multiplicities with the yield. Profit is calculated by the following method $\pi=\mathrm{I}-\mathrm{C}$, profit=income-cost in this case the study is calculating just with the cost of the fertilizers. Profitability on methane emission is calculated from the $\mathrm{CH}_{4}$ output and profit on the examined fertilizer (profit/methane emission). It will show how much profit can be earned on $1 \mathrm{~kg}$ methane emission. Theoretical tax payment after the production's methane emission is calculated from (tax rate/1000*methane emission*21), it has to be multiplied by 21 because of more powerful heat-trapping capacity compared to $\mathrm{CO}_{2}$. Carbon credit follows the same method, the amount of methane emission has to be multiplied by 21 (methane emission*21). ECX emission stock price calculation is the following (carbon credit*ecx emission index)

\section{LITERATURE}

Economics refers to elements that cannot be expressed in monetary terms as externalities. These do not form a part of the market, and if it is impossible to internalize them, it will also be impossible to obtain a clear picture of the systems examined. (Fogarassy és Nábrádi 2015) The methane emission can be solved by resultsbasedfinance forms relevant to Kyoto Protocol, which can also be more extended at the world-wide side by different financial institutions. Naturally this scenario is a possibility for accounting the innovative cost-effective methane reduction, but firms and governments are responsible for that how they use possibilities of scenario. Because firms should overcome financial, technical and international market obstacles, for example duty on the international markets (Török et al. 2015).

About carbon credit and tax. In Japan the Tax for Climate Change Mitigation applies from 2012 and covers the use of all fossil fuels except for certain parts of the agriculture, transport, industry and electricity production sectors. The coverage of the carbon tax is approximately $70 \%$ of the total GHG emissions. Tax

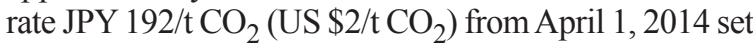
to increase to JPY $289 / \mathrm{t} \mathrm{CO}$ (US $\$ 3 / \mathrm{tCO}_{2}$ ) stepwise over 3.5 years. When the tax was introduced in October 2012 a third of the full tax rate was enforced. In April 2014 this doubled, and the full tax rate will be enforced from April 2016. Interesting features the revenues from the carbon tax will be used for measures to reduce energy-related $\mathrm{CO}_{2}$ emissions such as innovation in low-carbon technology, promotion of energy-saving equipment in small and medium-sized businesses and promotion of renewable energy (The World Bank 2014). One carbon credit usually represents the reduction of one metric ton of carbon dioxide or it is equivalent in other greenhouse gases such as methane and nitrous oxide. Methane and nitrous oxide have approximately 21 times and 310 times, respectively, the heat-trapping capacity of carbon dioxide. Reducing methane by one ton is equivalent to reducing carbon dioxide by 21 tons (Westerman et al. 2008). That means $47.6 \mathrm{~kg} \mathrm{CH}_{4}$ is equivalent to one ton $\mathrm{CO}_{2}$ which is one carbon credit.

\section{RESULTS AND DISCUSSION}

Matsuo paddy field is located in Central Japan, Kanto region, Chiba prefecture. The soil type of the field is sand-dune Regosol (Alluvial soil). The Reference Soil Group of the Regosols is a taxonomic rest group containing all soils that could not be accommodated in any of the other Reference Soil Groups. In practice, Regosols are very weakly developed mineral soils in unconsolidated materials that have only an ochric surface horizon and that are not very shallow (Leptosols), sandy (Arenosols) or with fluvic properties (Fluvisols). Regosols are extensive in eroding lands, in particular in arid and semi-arid areas and in mountain regions (FAO 2001).

The amount that have to be used on the field is $50 \mathrm{~kg}$ per are which means 100 JPY per are cost. The total cost will be 991.7 JPY for one tanbu. The third type of fertilizer which was mentioned above is the bacterial material. Bacterial material A is reported that it advanced rice straw decomposition on rice growing. Bacterial material A is a solution how to suppress the methane emission from the rice paddy fields. Bacterial material A contains zeolite and spores of Bacillus subtilis and Clostridium acetobutylicum (Hanazawa 2013). The price of bacterial material A is probably a bit high $1350 \mathrm{JPY}$ per $\mathrm{kg}$. In addition it has to be used with rice straw which is the same amount mentioned above $50 \mathrm{~kg} / \mathrm{a}$. $2 \mathrm{~kg}$ bacterial material is needed per are, so for one tanbu the cost will be 26816 JPY. In this cost the price of the rice straw is already calculated. This price is too high for competitive comparison so there is one more fertilizer type, this is bacterial material C. For the calculations everything will be the same in the model only the cost of the fertilizer will be changed. The cost of it $325 \mathrm{JPY} / \mathrm{kg}$ and $1.33 \mathrm{~kg} / \mathrm{a}$ has to be consumed so the cost for one are will be 432.25 JPY. The total cost for one tanbu is 1428.9 JPY. If all of the fertilizer's cost known it is time to get to know the yields. In the beginning of this research there was no data for yield equivalent to the size of the area, there was only calculations on yield/hill. To calculate the total yield we have to know how many hills can be found on one unit. At Matsuo paddy field there is 60 hill $/ 3 \mathrm{~m}^{2}$ known from the space between plants and row width. There is 20 hill $/ \mathrm{m}^{2}(60 / 3)$ and 19834.7 totally ((hill number/ $\left.\mathrm{m}^{2}\right)^{*}$ total area). The total number of hills at the field is known and the yield/hill is also known. Every data is available to calculate the total yield. Based on our data it is clear that the best achievable yield can be earned by bacterial material plus rice straw combination. This is more than $819 \mathrm{~kg}$ per 1 tanbu which is significantly higher than the national average which is $519 \mathrm{~kg} / 10$ are. In the case of rice straw and chemical fertilizer there is no significant differences between the yields. These are higher than the national average also but a bit smaller than with bacterial material treatment. The yield is over $700 \mathrm{~kg} / 10$ are.

Income: In the case of chemical fertilizer the income is $147511 \mathrm{JPY}$ per tanbu. The most yields are earned with bacterial material plus rice straw so the income will follow the same process. For bacterial material the 
income can be 163500 JPY per tanbu. For the rice straw there was no significant difference between the chemical fertilizer and the rice straw so the income is almost the same. Profit can be a lot of things in economics profit is the difference between income and costs. To make profit sometimes it is a must to make a deal, in Matsuo field's case this is how to earn more profit with less methane emission. "A New Capitalist Manifesto? Imagining Business in the $21^{\text {st }}$ Century." It focuses on the need to - and value of - balancing profit with purpose, and it contained a prediction: businesses in the future will recognize that the most successful companies are the ones that recognize the relationship, and can strike the appropriate balance, between higher purpose and financial success (Williams and Scott 2012).

In light of the three type of fertilizers the most profit can be earned by bacterial material $\mathrm{C}$ plus rice straw combination. From the total area 159000 JPY profit can be earned this way. If just only rice straw consumed at the process of rice production from the total area 149000 JPY profit can be earned. This happens because of the low price of the fertilizer and the relatively high yields. The third best choice if the chemical fertilizer used in the process of production. From the total area 14000 JPY can be earned. The costs are higher than the rice straw`s but the yields are a almost the same. The worst choice in this way is to use the bacterial material A. From the total area 130000 JPY profit can be earned by using that type of fertilizer. The yields are the highest but the costs also and they are significantly higher than the other options. Methane flux is the most important question in this study. What type of fertilizer has to be used to earn as few methane emissions as possible while we are considering the economics also? To know that the methane emission per each type of fertilizer have to be known. There are data for methane flux for each type of fertilizer in $\mathrm{Gc} / \mathrm{m}^{2}$. To calculate it for the whole field it look as $\left[\left(\right.\right.$ methane flux $\left./ \mathrm{m}^{2}\right) *$ total area/1000].

After this calculation there is data for how much methane emission is generated by each type of fertilizer in the size of the whole field. The emission is measured in $\mathrm{kg}$. The less methane emission is generated by the chemical fertilizer the value of it is $30-36 \mathrm{~kg} / \mathrm{tanbu}$. The bacterial material generated more methane than the regular chemical fertilizer but significantly less than the rice straw. The value of the methane emission generated by bacterial material is $48-50 \mathrm{~kg} / \operatorname{tanbu}$. The most methane is generated by the rice straw 63-73 $\mathrm{kg} / \mathrm{tanbu}$ methane is get to the atmosphere if the field is treated by rice straw. This value is two times higher than if the regular chemical fertilizer is used. It means rice straw is a very cheap alternative to nutrient supply but it will generate a lot of methane.

Above the results show the result of profit calculation, but if just rice straw consumed during the process of cultivation the methane emission will be high while the costs are low. In that case another method of calculating the profit has to be executed. It will be the profitability ratio on methane emission. This ratio will show how much profit generated on one unit methane emission. At Matsuo paddy field case that means how much profit generated on $1 \mathrm{~kg}$ methane emission. With this ratio it is really easy to compare what type of fertilizer efficient in light of methane flux. The calculation will be the following profitability $=\pi /\left[\left(\text { methane flux } / \mathrm{m}^{2}\right)^{*}\right.$ total area/1000]. The result shows that the most efficient method is to use chemical fertilizer during the process of production. On each $\mathrm{kg}$ methane emission 4000 4600 JPY profit generated. This is significantly higher than the other options. The second most efficient is bacterial material $\mathrm{C}$. The simple profit was the highest on bacterial material $\mathrm{C}$ but in light of methane emission it had a decent amount of methane flux that's why this is just our second option. Bacterial material $\mathrm{C}$ generates 3000-3300 JPY profit on one kilogram methane emission. This is result is significantly lower than if chemical fertilizer has been used, 1000 JPY profit is the difference on each $\mathrm{kg}$. Bacterial material $\mathrm{A}$ is the third option, it has all the benefits as bacterial material $\mathrm{C}$ but the profit is lower because of the high price of it. At all it will generate 2500-2800 JPY profit on $1 \mathrm{~kg}$ methane emission. The worst option is the rice straw. While rice straw was a considerable option at simple profit calculation now it is placed on last place. Why? Rice straw is a really cheap kind of fertilizer which produces a relatively high yield but the main problem is the methane emission. From field which is treated with rice straw $72.5 \mathrm{~kg}$ methane is released to the atmosphere while the field which is treated by chemical fertilizer the result is almost the half of it $36-37 \mathrm{~kg}$. In this case the profit what can be earned on each $\mathrm{kg}$ methane emission will be low as the result shows it is 2000-2100 JPY on $1 \mathrm{~kg}$ methane flux.

Matsuo paddy field is not a big one but it can generate one or a bit more than one carbon credit. Chemical fertilizer will affect the environment by 0.7 carbon credit while the rice straw is high as 1.5 carbon credit on $10 \mathrm{a}$. The bacterial material is over $1.0 \mathrm{cc}$ but it is lower than rice straw's. As the carbon credit values are known it is possible to calculate the carbon tax on it. For the year of 2014 the tax rate is $192 \mathrm{JPY} / \mathrm{t} \mathrm{CO}$ that means the tax after the chemical fertilizers' methane emission will be 145 JPY for the 10a area. After rice straw the owing will be 292 JPY for 10a. In the year of 2016 the tax will be higher 289 JPY per carbon credit. Chemical fertilizers' tax will be 218 JPY while rice straw's tax is $440 \mathrm{JPY}$ in 2016. These result also can be compared with the actual price of the (ICE) ECX emissions index on the stock which is $5.11 \mathrm{EUR} / \mathrm{MT}$ at the time of this study. It can be calculated based on the carbon credit value what is equal to 1 tonne $\mathrm{CO}_{2}$ emission (carbon credit*ECX emission index). Chemical fertilizer can produce the most favorable cost which is 3.1-3.8 EUR on the 10 are test field, if it is calculated on hectare that means 31-38 EUR cost on a unit. Rice straw produces the worst result, it would need 6.7-7.8 EUR input on 10 are while bacterial material $\mathrm{A}$ and $\mathrm{C}$ can do a much better result with the same price around 5.1-5.3 EUR cost on 10 are based on the field's methane emission carbon credit value.

\section{CONCLUSIONS}

As the result shows simple profit is not everything, the rice straw is a really good option for producing at low costs with high yield but it will lead to high methane emission from the paddy field. In this study 
the profitability on methane emission shows the most efficient way to cultivate rice while the profit is the highest at the same methane emission level. In the future if the carbon tax will be extended to rice production as well, lowering the emissions and the carbon credit after the methods of cultivation can save money. In that case it turned out that the chemical fertilizer has the biggest potential in profitability with low methane flux. In the future if the organic fertilizers are in focus than it is necessary to find a new material what can be competitive with the chemical fertilizers in this way. The new material need the following properties: low price, high amount of yield, low $\mathrm{CH}_{4}$ flux. If the material has all of these properties it is considered to be used at the fields. The amount of the methane emission depends on several factors, the fertilizer what was used during the production is only one, and further research is necessary in the climate, soil properties, water management. If the methane flux cannot be lowered it is advised to look for an alternative option. This can be the production of green energy. The biogas production from environmental and energy production aspects is also remarkable process, however, the effectiveness with new ways and new markets - can be significantly increased (Bai 2015). Rice production has enough potential to be a supplier for biogas production, it can be a good solution to use the methane for green energy.

\section{REFERENCES}

Bai, A. (2015): Local transport and waste management. Magyar Energetika. 1: 21-25

Bai, A.-Durkó, E.-Tar, K.-Tóth, J. B.-Lázár, I.-Kapocska, L.Kircsi, A.-Bartók, B.-Vass, R.-Pénzes, J.-Tóth, T. (2015): Social and economic possibilities for the energy utilization of fitomass in the valley of the river Hernád.

FAO (2001): FAOSTAT - Food and Agriculture Organization. FAO. Rome. Lecture notes on the major soils of the world. http:// www.fao.org/docrep/003/y1899e/y1899e07.htm

FAO (2016): FAOSTAT - Food and Agriculture Organization. FAO. Rome. http://faostat.fao.org/

Fogarassy, Cs.-Nábrádi, A. (2015): Proposals for low-carbon agriculture production strategies between 2020 and 2030 in Hungary. Apstract. 9. 4: 5-16.

Hadi, A.-Inubushi, K.-Yagi, K. (2010): Effect of water management on greenhouse gas emissions and microbial properties of paddy soils in Japan and Indonesia. Paddy and Water Environment. 8. 4: 319-324.

Hanazawa, S.-Takahashi, M.-Inubushi, K. (2013): Effects of bacterial material on straw decomposition and greenhouse gas emission from paddy soil.

IPCC (2007): Climate Change 2007: The physical science basis. Contribution of workgroup I to the fourth assessment report of the Intergovernmental Panel on Climate Change. Cambridge University Press. Cambridge. UK.

IPCC (2014): Climate Change 2014: Synthesis Report. Contribution of Working Groups I, II and III to the Fifth Assessment Report of the Intergovernmental Panel on Climate Change. [In: Pachauri, R. K.-Meyer, L. A. (eds.) Core Writing Team.] IPCC. Geneva. Switzerland. 151 .
Kato, S.-Iwaishi, S.-Inubushi, K. (2008): Effect of microbial material solution on methane emission from paddy soil. Hort. Research. 62: $39-44$

Minami, K. (1995): The effect of nitrogen fertilizer use and other practices on methane emission from flooded rice. Fertilizer Research. 40: 71-84.

Mosier, A. R.-Duxbury, J. M.-Freney, J. R.-Heinemeyer, O.Minami, K.-Johnson, D. E. (1998): Mitigating Agricultural Emissions of Methane. Climatic Change. 40: 39-80.

Popp, J.-Harangi-Rákos, M.-Pető, K.-Nagy, A. (2013): Bioenergy: Risks to food-, energy- and environmental security. Apstract. 7. 4-5: 121-130.

Stern, N. (2006): What is the Economics of Climate Change. World Economics. 7: 2 .

Török, T.-Szabó, L. Z.-Zsarnóczai, S. J. (2015): Methane Reductions to Moderate the Global Warming Effects. Apstract. 9. 4: 59-64.

Westerman, P. (2008): Carbon credits for methane emission and combustion. https://www.bae.ncsu.edu/extension/ext-publications/ waste/animal/ag-708-methane-westerman.pdf

Williams, D. K.-Scott, M. M. (2012): It's Time to Balance Profits and Purpose. Harvard Business Review. http://blogs.hbr.org/ 2012/09/its-time-to-balance-profits-an/

World Bank (2014): State and Trends of Carbon Pricing. Washington DC. USA 
